\title{
THE AMERICAN SPECIES OF THE ORB-WEAVER GENUS CAREPALXIS AND THE NEW GENUS RUBREPEIRA (ARANEAE: ARANEIDAE)
}

\author{
By HeRbert W. LeVI \\ Museum of Comparative Zoology, Harvard University, \\ Cambridge, Mass. 02138
}

\section{INTRODUCTION}

While the majority of species of Neotropical orb weavers are new, there are some exceptions. Spiders of unusual appearance, even though extremely rare, have been named. Apparently 19th century arachnologists searched through collections for unusual specimens to name. Regrettably, unlike most common, undistinguished spiders, the holotypes for some of the names of unusual spiders are immature specimens. Eight names compete for the apparently three, valid species of American Carepalxis. Three of the names are attached to immature holotypes. Immature spider holotypes, lacking the species characteristic genitalia, are difficult to place and if their names have priority may create nomenclatural problems.

Males of American species of both genera Carepalxis and Rubrepeira are unknown.

\section{Methods AND Materials}

The methods used in these revisions of Neotropical araneid orb weavers are described in some detail in a forthcoming revision of the genera Wixia, Pozonia, and Ocrepeira (Levi, in press).

Eye sizes are described using the diameter of the anterior median eyes as standard. For the anterior eye row, the distance between eyes is measured in the number of anterior median eye diameters; for the posterior row, the number of posterior median eye diameters.

The following collections contain specimens of Carepalxis and Rubrepeira. I thank their curators for making the spiders available.

${ }^{*}$ Manuscript received 2 July 1991 
AMNH American Museum of Natural History, New York, United States; N. Platnick, L. Sorkin

BMNH British Museum (Natural History), London, England; P. Hillyard, F. Wanless

CAS California Academy of Sciences, San Francisco, United States; W. J. Pulawski, D. Ubick

MACN Museo Argentino de Ciencias Naturales, Buenos Aires, Argentina; E. A. Maury

MCN Museu de Ciências Naturais, Porto Alegre, Rio Grande do Sul, Brazil; E. H. Buckup

MCZ Museum of Comparative Zoology, Cambridge, Massachusetts, United States

MECN Museo Ecuatoriano de Ciencias Naturales, Quito, Ecuador; L. Avilés

MNHN Muséum National d'Histoire Naturelle, Paris, France; J. Heurtault, C. Rollard

MNRJ Museu Nacional, Rio de Janeiro, Brazil; A. Timotheo da Costa

MZSP Museu de Zoologia da Universidade de São Paulo, São Paulo, Brazil; P. Vanzolini, L. Neme, J. L. M. Leme

PAN Polska Akademia Nauk, Warszawa, Poland; W. Starega, J. Proszynski, A. Slojewska, E. Kierych

ZMH Zoologisches Institut und Museum, Hamburg, Germany; G. Rack

The research was started with support of National Science Foundation Grant GB 36161. I am also grateful to H. D. Cameron who loaned a specimen of Carepalxis, L. B. Leibensperger who helped in all parts of the research, and C. D. Dondale for carefully reading the manuscript and suggesting improvements.

\section{Carepalxis L. Koch}

Carepalxis L. Koch, 1872: 123. Type species by monotypy $C$. montifera L. Koch, 1872: 123. The gender of the name is feminine (Bonnet, 1956: 954).

Notes. The female holotype of Carepalxis montifera is in the ZMH and comes from Port Mackay [Mackay, Queensland], Australia. It has been examined for this revision. Its abdomen is 
shrivelled and the scape torn off. A better specimen of this species has recently been illustrated by Davies (1988: 302).

Diagnosis. The carapace differs from that of most other araneids and especially from the related Scoloderus, Wixia and Ocrepeira by having two humps or tubercles (Figs. 4, 5, 8-10, 15-17). Such humps are also present in Gasteracantha. The related Scoloderus differs by having one carapace hump larger and median (Levi 1976, figs. 125, 126) and by being much smaller in size with the abdomen having paired humps or being shield-shaped (Levi, 1976, figs. 126, 128). Gasteracantha differs by having a heavily sclerotized abdomen, which is usually wider than long and has lateral spines and sclerotized muscle scars (Levi, 1978, figs. 69-72).

Description. The cephalic region is the same color as the thoracic region and is covered by short setae. The sternum is yellow to dark; the legs are dark and ringed and the pattern on the dorsum of the abdomen is variable among specimens of the same species. The venter of the abdomen is gray with a pair of large white patches. Carepalxis salobrensis has a wavy black line on its side (a pattern also found in Ocrepeira species; Levi, in press). The eyes are subequal and the cephalic region of females is wide, more than half the maximum diameter of the carapace. The abdomen is high and has tubercles (Figs. 4, 8, 9, 15, 16).

The epigynum is heavily sclerotized, triangular to square in $C$. salobrensis, resembling that of Ocrepeira (Levi, in press). The southernmost of the three species, C. camelus, which has a long, flat scape, is closest to the Australian C. montifera.

The only reported male (Simon 1896) is that of the Australian C. tuberculatus Keyserling, 1886. Examining Simon's specimens, I found two males which were collected with females (MNHN 17897). One male is $4.5 \mathrm{~mm}$ total length, and lacks the carapace humps present in the female; in the location of the humps there are slight swellings in a light field, emphasized by a darker posterior region. The oval abdomen has five pairs of tubercles, although the female of this species has only two pairs, both anterior. The chelicerae of the male are concave, an adaptation to the relatively large palpus. The palpal patella has one macroseta, the endite a tooth, the first coxa a hook, the third and fourth coxae are unarmed. The second tibia has a branch tipped by two macrosetae, as in Verrucosa (Levi, 1976, fig. 7). The palpus has a 
mushroom-shaped, stalked paramedian apophysis, a long tubeshaped median apophysis (matching the long female scape), and as in Eriophora, a narrow cymbium. The terminal apophysis appears fused to the subterminal apophysis and embolus, and the total structure is hinged to the radix. The embolus appears tube-shaped and hidden behind a large lamella (the palpus was not pulled apart).

Relationship. The humps on the carapace and the high clypeus are probably homologous with those of Scoloderus, but not homologous to with those of Gasteracantha. The coloration, posterior transverse bars on the dorsal side of the abdomen, the black wiggly lines on the sides of the abdomen, and ventral paired white patches on dark (of C. salobrensis, Fig. 16), are homologous to those of Ocrepeira. The three median posterior tubercles of $C$. perpera are homologous with similar tubercles found in species of Wagneriana and Parawixia. The absence of these tubercles in two of the species might be due to secondary loss, or perhaps they're not expressed in the adult female in order to provide maximum space for silk glands and eggs.

Distribution. Nine nominal species are known from Australia (Roewer, 1942) and three from the Neotropics.

Misplaced species. The complete citations are in Roewer (1942) and Brignoli (1983).

americanus O. P.-Cambridge, 1889, belongs in Scoloderus.

bispinosa Mello-Leitão, 1945, belongs in Ocrepeira (Levi, in press).

nigriceps O. P.-Cambridge, 1895, is Scoloderus cordatus (Taczanowski), (Levi, 1976).

normalis Keyserling, 1892, belongs in Scoloderus. NEW COMBINATION

tuberculifer O. P.-Cambridge, 1889, is Scoloderus cordatus (Taczanowski), (Levi, 1976).

\section{Key to American CAREPALXIS}

1 Epigynum with a scape more than twice as long as wide (Figs. $1,3)$; posterior median plate hidden by lateral plates in posterior view (Fig. 2); Paraguay and northern Argentina ....camelus 
- Epignum with a shorter scape or without scape (Figs. 6, 11, 13); posterior median plate visible in posterior view (Figs. 7, $12,14)$

2(1)Epigynum without scape (Figs. 11, 13); abdomen subspherical with 1 or 2 pairs of anterior humps (Fig. 15); Mexico to Peru and Brazil.............................................................salobrensis

- Epigynum with oval scape (Fig. 6); abdomen with 5 pairs of tubercles and 3 median, posterior tubercles (Figs. 8, 9); Baja California, Mexico.

perpera

\section{Carepalxis camelus Simon}

Figures 1-5; Map 1

Carepalxis camelus Simon, 1895: 157. Two female syntypes from Paraguay, in MNHN no. 193, examined. Roewer, 1942: 865. Bonnet, 1956: 954.

Carepalxis vianai Gerschman and Schiapelli, 1948: 16, figs. 22-25, ९. Female holotype from Santa María, Misiones Prov., Argentina, in MACN no. 1835, examined. Brignoli, 1983: 264. NEW SYNONYMY.

Synonymy. The structure of the genitalia and body shape of $C$. vianai is as in $C$. camelus.

Description. Female holotype of $C$. vianai. Carapace orange with abundant orange setae. Chelicerae orange with dark patch. Sternum light orange. Legs yellow with brown rings. Dorsum of abdomen orange-white with some black spindle-shaped setae; venter whitish with black scales. Eyes subequal in size. Anterior median eyes 1.5 diameters apart. Posterior median eyes two diameters apart. Height of clypeus equals three diameters of anterior median eye. Chelicerae with four teeth on anterior margin, three on posterior. Legs short and thick. Abdomen suboval with anterior humps (Fig. 4). Total length $6.0 \mathrm{~mm}$. Carapace $2.9 \mathrm{~mm}$ long, 2.7 wide, behind lateral eyes 1.9 wide. First femur $2.8 \mathrm{~mm}$, patella and tibia 3.1 , metatarsus 2.1, tarsus 0.8 . Second patella and tibia 3.1 $\mathrm{mm}$, third 2.0, fourth 2.7. First tibia $0.4 \mathrm{~mm}$ wide.

Illustrations. Figures 1-5 were made from the holotype of $C$. camelus.

Diagnosis. This species is closest to the type species of the genus Carepalxis: C. montifera L. Koch of Australia. It differs from the other two American species by having an epigynum with a long scape (Figs. 1, 3) and by the shape of the carapace and abdomen (Figs. 4, 5). 


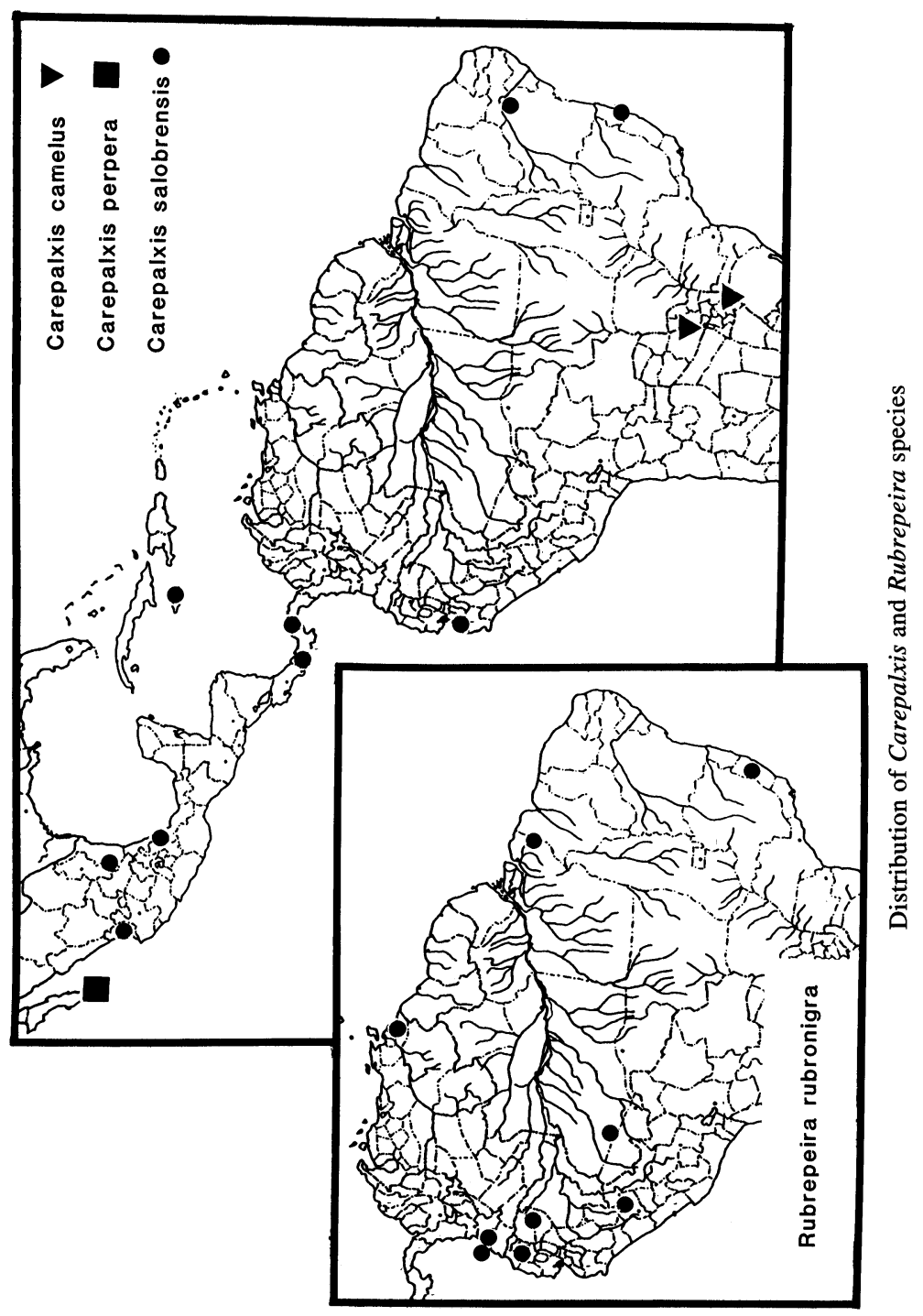



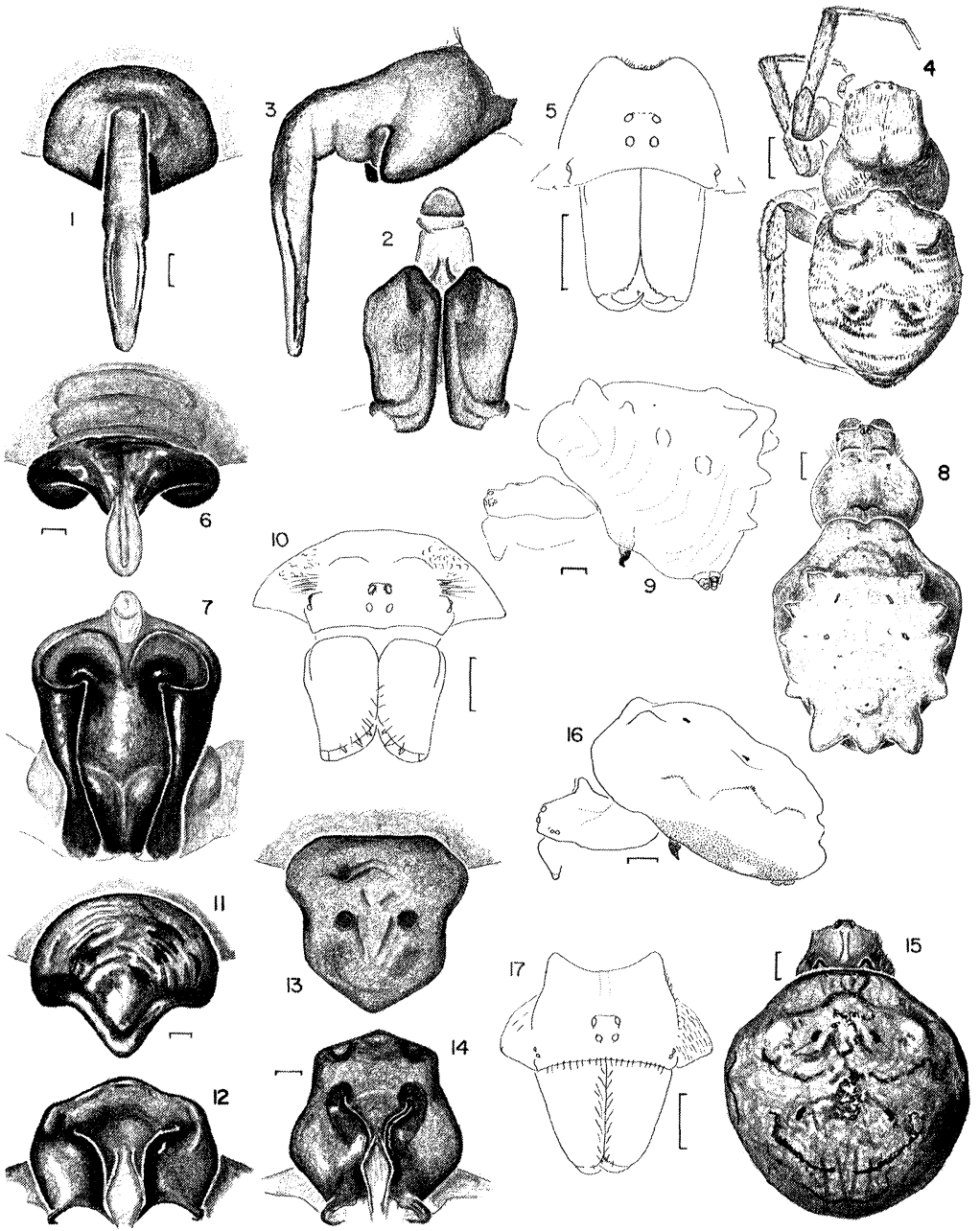

Figures 1-5. Carepalxis camelus Simon, female. 1-3, epigynum. 1, ventral. 2, posterior. 3 , lateral. 4 , dorsal, 5 , eye region and chelicerae.

Figures 6-10. C. perpera (Petrunkevitch), female. 6, 7, epigynum. 6, ventral. 7, posterior. 8, dorsal. 9, lateral. 10, eye region and chelicerae.

Figures 11-17. C. salobrensis Simon, female. 11-14, epigynum. 11, 13, ventral. 12, 14, posterior. 11, 12, (from Tepic, Mexico). 13, 14, (from Jamaica). 15, dorsal. 16, lateral. 17, eye region and chelicerae.

Scale lines, $1.0 \mathrm{~mm}$, genitalia $0.1 \mathrm{~mm}$. 
Specimens Examined. The species is known only from the type specimens of the two names.

Carepalxis perpera (Petrunkevitch), new combination

Figures 6-10; Map 1

Epeira perplexa Banks, 1898: 251, pl. 15, fig. 1, o. Female holotype from Sierra

San Nicolas [Cerro San Nicolas], Baja California [Sur], Mexico, in CAS, destroyed in California earthquake of 1906. Name preoccupied by Epeira perplexa Walckenaer, 1842: 101 (a Cyclosa).

Araneus perperus Petrunkevitch, 1911: 309. New name for E. perplexa Banks. Bonnet, 1955: 565.

Aranea perpera: - Roewer, 1942: 849.

Note. Banks illustrated the original female. It has a longer scape than the only adult specimen examined. Banks' specimen may have been an immature before its last molt which, in some species of araneids, has a soft scape.

Description. Female from S Miraflores, Baja California Sur. Carapace orange with long white setae behind eyes and fine curly setae on sides of thorax (Fig. 8). Chelicerae orange-brown. Labium brown, endites orange. Sternum dusky in center, sides orange. Coxae orange with brown patches; legs orange with brown rings, patellae darkest. Dorsum of abdomen grayish white (Fig. 8); venter grayish white. Posterior median eyes same diameter as anterior medians, laterals 0.8 diameter. Anterior median eyes 1.6 diameters apart. Posterior median eyes 1.5 diameters apart. Ocular quadrangle slightly narrower behind than in front. Height of clypeus equals 1.5 diameters of anterior median eye. Abdomen with four pairs of lateral humps and three median posterior humps (Fig. 8). Total length $15.5 \mathrm{~mm}$. Carapace $5.5 \mathrm{~mm}$ long, 4.4 wide, behind lateral eyes 2.7 wide. First femur $5.4 \mathrm{~mm}$, patella and tibia 7.3, metatarsus 4.2, tarsus 1.5. Second patella and tibia $6.4 \mathrm{~mm}$, third 3.6, fourth 5.6.

Illustrations. Figures 6-10 were made from the only adult female available.

Diagnosis. Carepalxis perpera differs from the two other American species by having the abdomen with five pairs of lateral tubercles and three posterior median dorsal tubercles (Figs. 8, 9) and by the wide, elongate, posterior median plate of the epigynum (Fig. 7). 
Specimens Examined. MEXICO Baja California Sur: $8 \mathrm{~km} \mathrm{~S}$ Miraflores, 11 July 1938, @ (A. E. Michelbacher, E. S. Ross, CAS); "cape region", imm. (N. Banks, MCZ).

\section{Carepalxis salobrensis O. P.-Cambridge}

Figures 11-17; Map 1

Carepalxis salobrensis Simon, 1895: 157. Immature holotype from Rio Salobro, [Bahia State], Brazil, in MNHN no. 8494, examined. Roewer, 1942: 865. Bonnet, 1956: 954.

Carepalxis gibbosa O. P.-Cambridge, 1889: 48, pl. 4, fig. 10, imm. Immature holotype from Bugaba, [Chiriquí Prov.], Panama, in BMNH no. 1905.4.28.3212, examined. Keyserling, 1892: 54, pl. 2, fig. 43, imm. Roewer, 1942: 865. Bonnet, 1956: 954. NEW SYNONYMY

Carepalxis rotunda O. P.-Cambridge, 1896: 224, pl. 27, fig. 7, imm. Immature holotype from Atoyac, Veracruz State, Mexico, in BMNH no. 1905.4.28.3213, examined. Roewer, 1942: 865. Bonnet, 1956: 954. NEW SYNONYMY

Carepalxis eremita Archer, 1966: 131, pl. 1, fig. 2, 3, ९. Female holotype from Hermitage Reservoir, Jamaica, in AMNH, examined. Brignoli, 1983: 264. NEW SYNONYMY

Synonymy. The $C$. salobrensis holotype is $5.8 \mathrm{~mm}$ long, with carapace $2 \mathrm{~mm}$ wide; the $C$. rotunda holotype is $4.5 \mathrm{~mm}$ long, with carapace $1.7 \mathrm{~mm}$ wide; the $C$. gibbosa holotype has the carapace $2.0 \mathrm{~mm}$ wide. Both $C$. rotunda and C. gibbosa holotypes are in two parts and damaged by insect pins. The shape of the abdomen, the carapace bulges, and the concavity between the carapace bulges are the same as those of the mature specimen from Tepic, Mexico, which is illustrated (Figs. 15-17). An adult female confirms that the species is found as far south as Bahia State, Brazil. This adult is very similar in marks, color and structure to the holotype of $C$. salobrensis. Its epigynum is like that illustrated of the specimen from Jamaica (Figs. 13, 14).

Description. Female from Tepic, Mexico. Carapace dark orange with white setae. Chelicerae orange-brown with dark patch. Labium, endites brown. Sternum orange with white pigment underneath transparent exoskeleton and dark border. Coxae dark orange; legs orange with dark rings and streaks. Dorsum of abdomen whitish with dusky and black marks (Fig. 15); venter black with a pair of white patches their diameter apart (Fig. 16). Posterior median eyes same diameter as anterior medians, laterals 0.7 diameter. Anterior median eyes 0.9 diameter apart. Posterior median eyes two diameters apart. Ocular quadrangle wider behind than in 
front. Height of clypeus equaling almost two diameters of the anterior median eye (Fig. 17). Abdomen with a pair of lateral humps and a smaller confluent pair in between and slightly anterior (Fig. 15). Total length $9.8 \mathrm{~mm}$. Carapace $4.1 \mathrm{~mm}$ long, 3.7 wide, behind lateral eyes 2.5 wide. First femur $4.1 \mathrm{~mm}$, patella and tibia 5.0, metatarsus 3.4, tarsus 1.1. Second patella and tibia $4.7 \mathrm{~mm}$, third 2.9, fourth 4.4. Second tibia in dorsal view $0.7 \mathrm{~mm}$ wide.

Variation. Total length of females 7.6 to $11.8 \mathrm{~mm}$. None of the five adult females have the outline of the epigynum in ventral view alike (Figs. 11, 13). Most have the outline of the epigynum closer to the specimen from Jamaica (Figs. 13, 14) than the one from Mexico. The posterior face of the epigynum varies only in the width of the median plate (Figs. 12,14). The adult female from Bahia State, Brazil and the holotype of $C$. salobrensis are the only ones lacking two white patches on the underside of the abdomen. Illustrations were made from the female from Tepic, Mexico, and Figures 13, 14 from the holotype of $C$. eremita from Jamaica.

Diagnosis. The shape of the abdomen, round in outline with one or two pairs of anterior dorsal humps (Fig. 15), and the posterior view of the epigynum (Figs. 12, 14) separate this from the other Carepalxis species.

Specimens Examined. MEXICO Tamaulipas: $1.5 \mathrm{~km}$ E Santa María Guadalupe, $43 \mathrm{~km}$ E Tula, $320 \mathrm{~m}, 8$ June 1983, imm. (W. Maddison, MCZ). Nayarit: Tepic, 26 July 1953, o (P. \& C. Vaurie, AMNH). PANAMA Panamá: Forest Reserve, Aug. 1936, early instar imm. (A. M. Chickering, MCZ); Barro Colorado Isl., Lago Gatún, 16 June - 15 July, 1934, imm. (A. M. Chickering, MCZ). PERU Tumbes: Lechugal, 2o (K. Jelski, J. Sztolcman, PAN). BRAZIL Bahia: Fazenda Goiarema, Mucurí, 14 May 1979, o (A. C. Niella, MCN 10125).

\section{Rubrepeira new genus}

The type species is Verrucosa rubronigra Mello-Leitão. The generic name is an arbitrary combination of letters attached to Epeira, and is feminine.

Diagnosis. This genus is close to Alpaida and Wagneriana (and also the African Megaraneus Lawrence, 1968) but differs by having a low, flat, setose carapace and by the unusual shape of the 

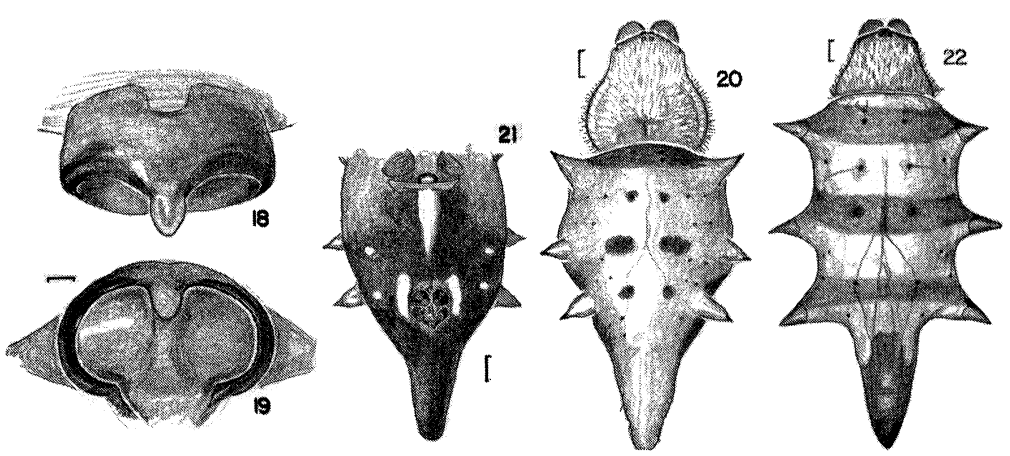

Figures 18-22. Rubrepeira rubronigra (Mello-Leitão), female. 18, 19, epigynum. 18 , ventral. 19 , posterior. 20,22 , dorsal. 21 , ventral.

Scale lines, $1.0 \mathrm{~mm}$, genitalia $0.1 \mathrm{~mm}$.

abdomen, which has only one posterior median projection and three pairs of lateral spine-shaped projections (Figs. 20-22).

Note. The large size of the females and the complete absence of male or last instar males in collections suggests that the male might be dwarfed. Since the shape of the epigynum resembles that of Alpaida and Wagneriana females, I expect the male palpus to be similar to that of males of these genera or perhaps less complex because of its small size. Based on the palpal characters of Alpaida and Wagneriana I expect the following: a paramedian apophysis on the side of the conductor pointing toward the radix; the conductor attached some distance from the rim of the tegulum; small distal hematodocha between embolus and terminal apophysis; median apophysis without large hooks or spines and directly attached to the tissue behind the radix (not as in Araneus relatives, with the attachment offset behind the median apophysis).

This species can not be placed in Verrucosa because Verrucosa species do not have as flat a carapace; Verrucosa have an abdomen as wide as long or wider than long; it is widest anteriorly and usually bears a line of three median posterior tubercles. The Verrucosa epigynum has a long scape usually hinged anteriorly (Levi, 1976; Lise, in preparation).

Only one species, $R$. rubronigra, is known. 
Rubrepeira rubronigra (Mello-Leitão), new combination

Figures 18-22; Map 1

Verrucosa rubronigra Mello-Leitão, 1939: 110, figs. 12, 13. Immature female holotype from Colatina, Espírito Santo State, Brazil, in MNRJ, lost. Roewer, 1942: 879. Bonnet, 1959: 4791.

Acrosoma riscoi Archer, 1971: 158, figs. 3, 4, o. Female holotype from Cueva de la Pava, Tingo María, Depto. Huánuco, Peru, in AMNH, examined. NEW SYNONYMY

Note. A. A. Lise (in litteris) confirmed that the holotype of $V$. rubronigra could not be found. However an immature paratype of the name, from Guyana, belonging to the $\mathrm{BMNH}$, was available.

Archer placed this species in Acrosoma. Acrosoma, with the type species A. swainsoni Perty (designated by F. P.-Cambridge, 1904: 525) is a subjective synonym of Micrathena Sundevall with the type species M. clypeata Walckenaer (Levi, 1985: 440).

Description. Female from Cauca, Colombia. Carapace orange with white hair, area between eyes darker, light band on each side of thoracic region. Chelicerae orange. Labium, endites orangeblack. Sternum orange-black. Coxae, legs orange-black. Dorsum of abdomen whitish with paired black marks, lateral spines orange (Figs. 20, 22); venter black with white median streak and white patch on each side of spinnerets (Fig. 21). Cephalic region of carapace low. Eyes subequal. Anterior median eyes their diameter apart. Posterior median eyes slightly more than their diameter apart. Abdomen with three pairs of lateral spines and a posterior median projection (Figs. 20-22). Total length $19 \mathrm{~mm}$. Carapace $5.3 \mathrm{~mm}$ long, 4.8 wide. First femur $8.0 \mathrm{~mm}$, patella and tibia 8.1, metatarsus 5.9, tarsus 1.9. Second patella and tibia $7.3 \mathrm{~mm}$, third 4.1, fourth 7.2.

Variation. Total length of females 15 to $20 \mathrm{~mm}$. Many females, including the holotypes of both names, have transverse dorsal black bands on red, six orange spines, and black posterior spine (Fig. 22). Between the red and black bands is a narrow yellow line. Figures 18-21 were made from a female collected in Depto. Cauca, Colombia, Figure 22 from the holotype of A. riscoi.

Diagnosis. The bright coloration as well as the ventral markings of the abdomen (Figs. 20-22) are diagnostic.

Natural History. W. Eberhard reports (in litteris) that the female collected by K. Mullen came from a more or less horizontal web, 2 $\mathrm{m}$ above ground in mangroves. An immature paratype of $V$. 
rubronigra from Guyana came from a Sceliphron fistulare (Dahlb.) wasp nest together with Alpaida trispinosa (Keyserling). The immature from Montalvo, Ecuador came from a sphecid wasp nest.

Specimens examined. MEXICO $150 \mathrm{~km}$ NE of Barranco [?], 1 Aug. 1958, o (A. S. Menke, AMNH). GUYANA imm. (BMNH). VENEZUELA Delta Amacuro: Caño Jobure, 7 April 1955, ९ (J. J. Wurdack, AMNH). COLOMBIA Cauca: Isla Gorgona, Pacific Ocean, Feb. 1961, o (F. Medem, H. D. Cameron Coll.); Borbona Island Town [?], 5 m, ᄋ (M. Barreto, MCZ); Guapí, Aug. 1975, ᄋ (W. Eberhard, K. Mullen, MCZ). ECUADOR Pichincha: Rto. A. Perez Intriago, km 113, Via Puerto Quito, 1 June 1985, imm. (T. Gramizo, MECN). Pastaza: Montalvo, 14 Aug. 1985, imm. (D. Bástidas, MECN). BRAZIL Pará: Rio Gurupi, 10-26 Apr. 1963, imm. (B. Malkin, MZSP 3362). Amazonas: mouth of Rio Embira, Rio Juruá, 1933, imm. (B. A. Krukoff, AMNH).

\section{SUMMARY}

There are three species of Carepalxis in America: C. camelus, $C$. perpera and $C$. salobrensis. Only females of these species are known. Carepalxis vianai is synonymized with $C$. camelus; $C$. gibbosa, $C$. rotunda and $C$. eremita with $C$. salobrensis. Carepalxis bispinosa belongs in Ocrepeira; $C$. normalis in Scoloderus. The new genus Rubrepeira is for Verrucosa rubronigra. Acrosoma riscoi is a synonym of $R$. rubronigra.

\section{Literature CITED}

ARCHER, A. F.

1966. Nuevos Argiopidos (Arañas) de las Antillas. Caribbean Jour. Sci., 5: 129-133.

1971. Especies Nuevas de Argiopidos Peruanos. Rev. peru. Entomol. agric. 14: $157-159$.

BANKS, N.

1898. Arachnida from Baja California and other parts of Mexico. Proc. California Acad. Sci. ser. 3, 1: 205-308.

BONNET, P.

1955. Bibliographia Araneorum. Toulouse 2 (1): 1-918.

1956. Bibliographia Araneorum. Toulouse 2 (2): 919-1925

BRIGNOLI, P.

1983. A catalogue of the Araneae described between 1940 and 1981. Manchester University Press, Manchester, 755 pp. 
CAMBridge, F. P.-

1897-1905. Arachnida, Araneidea and Opiliones. 2: 1-610. In Biologia Centrali-Americana, Zoologia, London.

CAmbridge, O. P.-

1889-1902. Arachnida, Araneidea. 1: 1-317. In Biologia Centrali-Americana, Zoologia, London.

1896. On some new and little known spiders. Proc. Zool. Soc., London, 1896: 1006-1012.

DAVIES, V. T.

1988. An illustrated guide to the genera of orb-weaving spiders in Australia. Mem. Queensland Mus. 25: 273-332.

Gerschman de Pikelin, B. S., AND R. D. SchiaPelli

1948. Arañas Argentinas II. Comm. Museo Argentino Cienc. Natur. Ser. Cienc. Zool., 1(4): 1-20.

KEYSERLING, E.

1886. Die Arachniden Australiens, Nürnberg, 2: 87-152.

1892-1893. Die Spinnen Amerikas, Epeiridae, Nürnberg, 4: 1-377.

KоCH, L.

1872. Die Arachniden Australiens. Nürnberg. pp. 105-368.

LEVI, H. W.

1976. The orb-weaver genera Verrucosa, Acanthepeira, Wagneriana, Acacesia, Wixia, Scoloderus, and Alpaida North of Mexico. (Araneae: Araneidae). Bull. Mus. Comp. Zool. 147: 351-391.

1978. The American Orb-weaver Genera Colphepeira, Micrathena and Gasteracantha North of Mexico (Araneae, Araneidae). Bull. Mus. Comp. Zool. 148: 417-442.

1985. The spiny orb-weaver genera, Micrathena and Chaetacis (Araneae: Araneidae). Bull. Mus. Comp. Zool. 150: 429-615.

in press. The orb-weaver genera Wixia, Pozonia and Ocrepeira (Araneae: Araneidae). Bull. Mus. Comp. Zool.

Mello-Leitão, C. DE

1939. Some new argiopid spiders of British Guiana taken by Mr. C. W. Richards from the nests of solitary wasps. Ann. Acad. Brasileira Scienc. 11: 105-112.

Petrunkevitch, A.

1911. A synonymic index-catalogue of spiders of North, Central and South America with all adjacent islands. Bull. American Mus. Natur. Hist. 29: $1-791$.

Roewer, C. F.

1942. Katalog der Araneae von 1758 bis 1940. Bremen, 1: 1-1040.

Simon, E.

1895. Descriptions d'espèces et de genres nouveaux de l'ordre Araneae. Ann. Soc. entomol. France, 64: 131-160.

1896. Liste der Arachniden der Semon'schen Sammlung in Australien und dem Malayischen Archipel. Jenaische Denkschrift. 8: 341-352. 

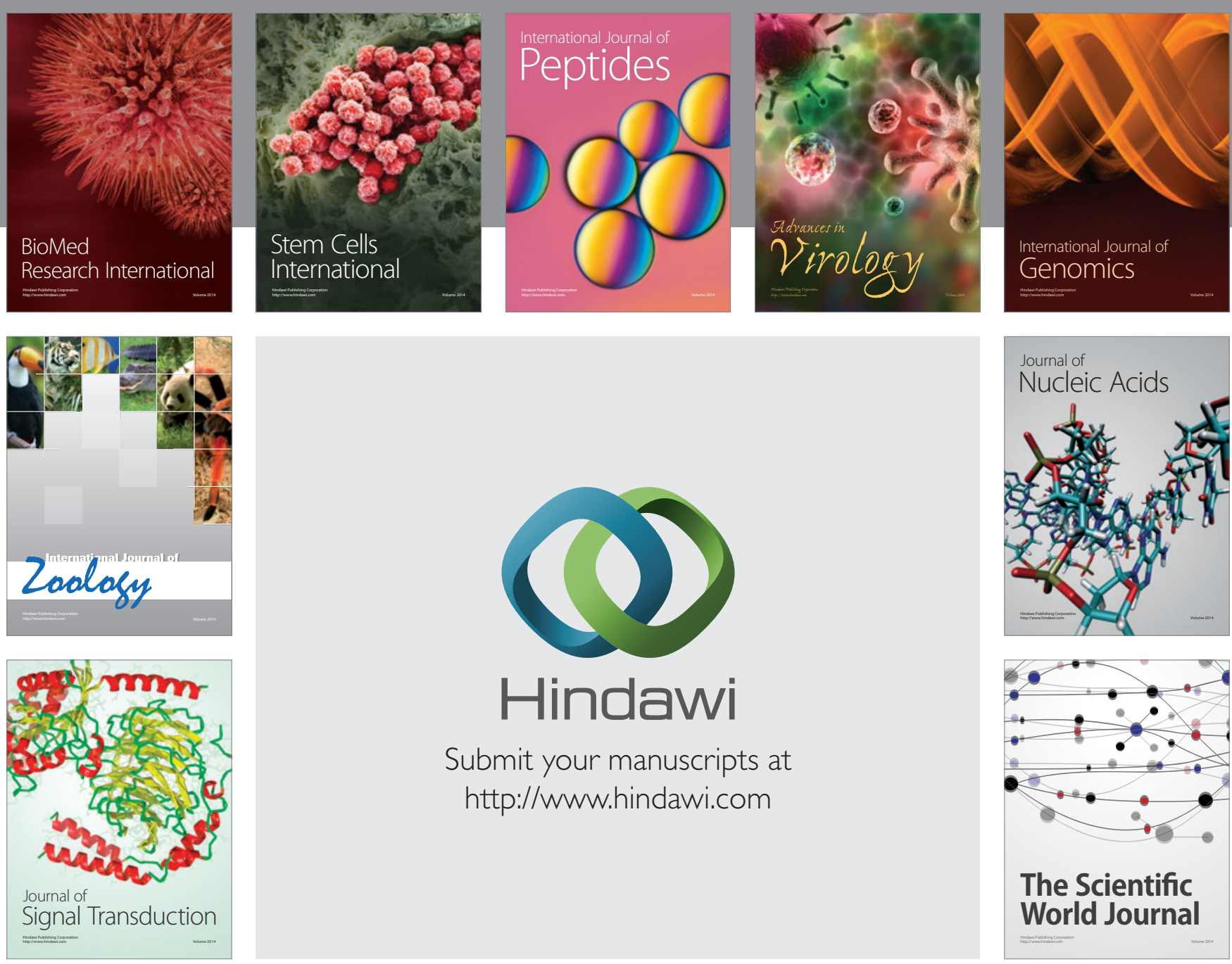

Submit your manuscripts at

http://www.hindawi.com
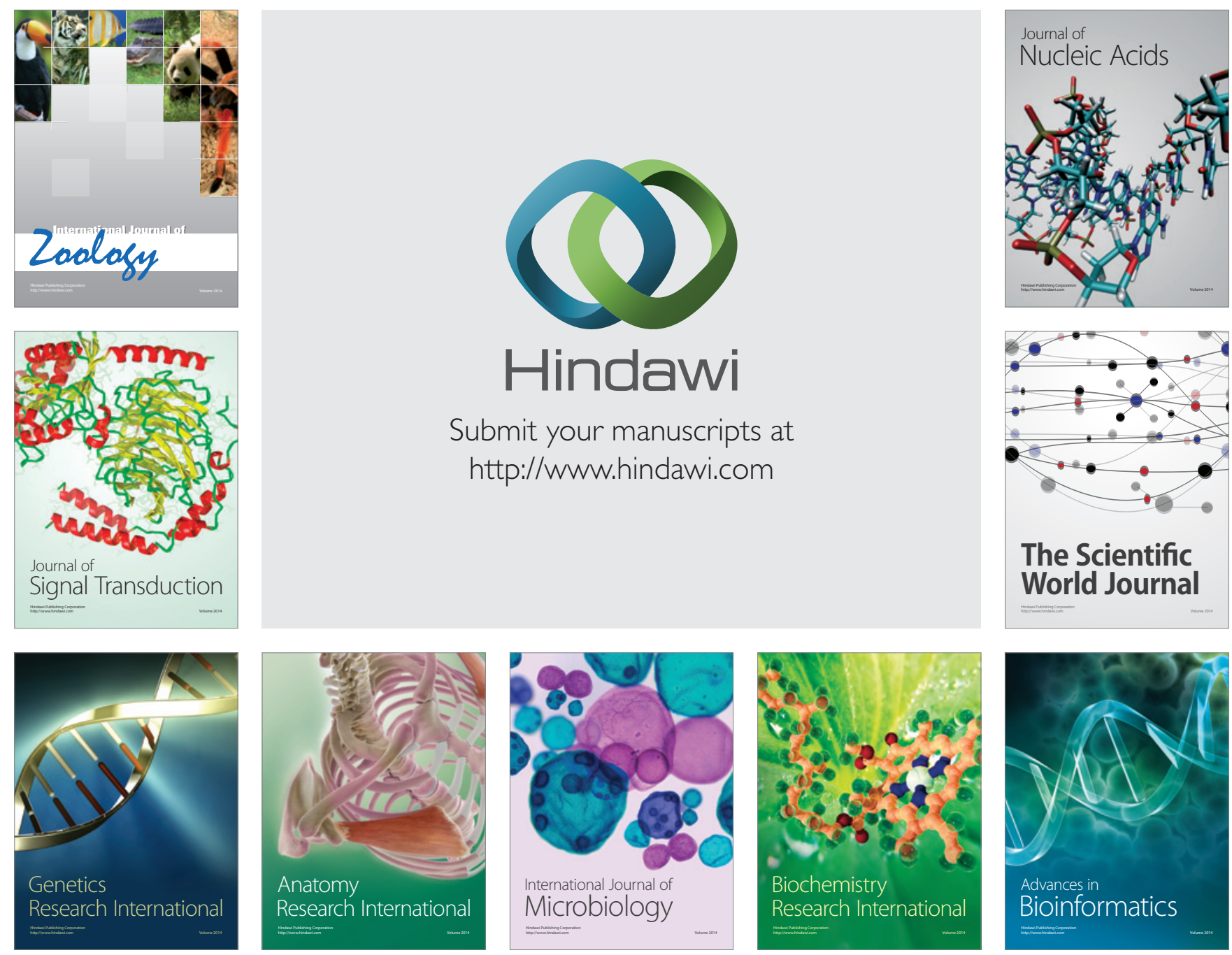

The Scientific World Journal
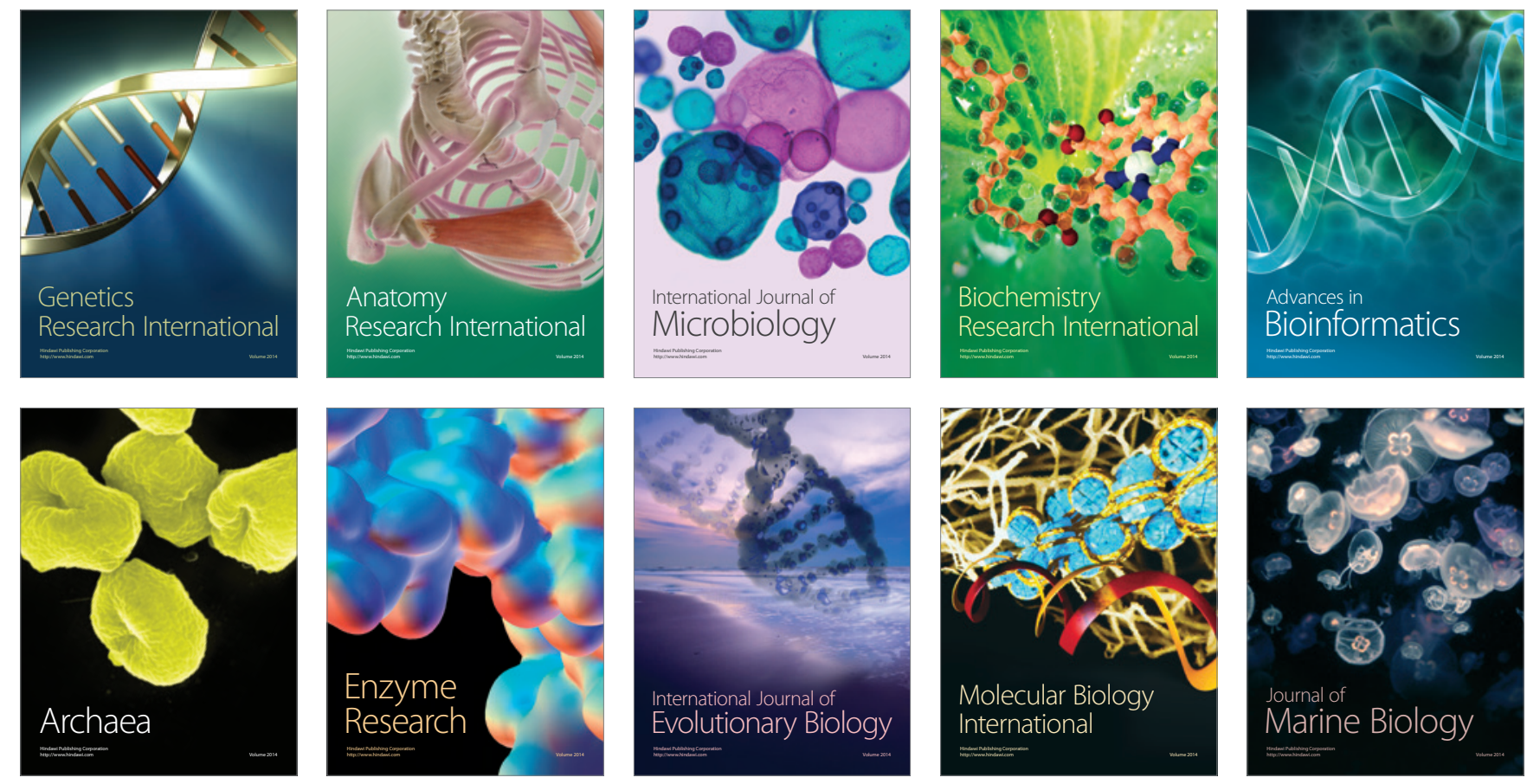